\title{
Telepsychiatry Practices in Children and Adolescents During the COVID-19 Outbreak: Case Series and Mini Review
}

\author{
COVID-19 Salgını Sirasında Çocuk ve Ergenlerde Telepskiyatri Uygulamaları: Olgu Serisi ve Kısa \\ Derleme
}

(1) Sefa Coşğun, (1) Eray Fadıloğlu

Van Training and Research Hospital, Clinic of Child and Adolescent Psychiatry, Van, Turkey

The Coronavirus disease-2019 (COVID-19) pandemic, which affected the whole world, had severe effects on children and adolescents, psychiatric disorders appeared, and existing psychiatric symptoms exacerbated. With the measures taken to reduce the spread of the Severe acute respiratory syndrome coronavirus-2 (SARS-CoV-2) virus, and changes in the health system, it has been difficult for children and families to access mental health services. Globally, the usage of telepsychiatry applications has increased, and various help has been provided to children and families through online platforms. When Turkish literature was reviewed, we came across a limited number of articles on telepsychiatry practices in children and adolescents. In this article, four cases diagnosed with Attention Deficit and Hyperactivity Disorder, Autism Spectrum Disorder, Major Depression Disorder, Substance Use Disorder were presented, who were followed by telepsychiatry, and recommendations for future arrangements were made by reviewing the literature.
\end{abstract}

Keywords: COVID-19, pandemic, telepsychiatry, child, adolescent, case series

Bütün dünyayı etkileyen Koronavirüs hastalığı-2019 (COVID-19) salgının çocuk ve ergenler üzerinde ciddi etkileri olmuştur. Salgınla beraber bir kısım çocuk ve ergende psikiyatrik bozukluklar ortaya çıkmış, öncesinde psikiyatrik semptomları olanlarda alevlenmeler görülmüştür. Salgın kapsamında Şiddetli akut solunum sendromu koronavirüs-2 (SARS-CoV-2) virüsünün yayılımını engellemek için alınan önlemler ve sağlık sisteminde yapılan değişiklikler ile çocuk ve ailelerin ruh sağlığı hizmetlerine ulaşmaları oldukça zorlaşmıştır. Bu süreçte tüm dünyada telepsikiyatri uygulamalarının kullanımı yaygınlaşmış, çevrimiçi platformlar aracılığıyla çocuklara ve ailelere çeşitli hizmetler sunulmuştur. Ülkemizdeki yayın dizini incelendiğinde çocuk ve ergenlerdeki telepsikiyatri uygulamaları ile ilgili kısıtlı sayıda yazıya denk gelinmiştir. Bu yazıda Dikkat Eksikliği ve Hiperaktivite Bozukluğu, Otizm Spektrum Bozukluğu, Majör Depresyon Bozukluğu, Madde Kullanım Bozukluğu tanıları almış dört olgunun telepsikiyatri ile takibi sunulmuş, literatür incelenerek ileride yapılacak düzenlemeler için önerilerde bulunulmuştur.

Anahtar Kelimeler: COVID-19, pandemi, telepsikiyatri, çocuk, ergen, olgu serisi

\section{Introduction}

In the recent epidemiological study conducted in Turkey, at least one psychiatric disorder was found in one out of five children and adolescents. ${ }^{1}$ Although there are children and adolescents needing help, there are still not enough mental health experts working in this field. In addition to the insufficient number of existing professionals, the fact that most of the experts work in metropolitan areas is another challenge for children and families living outside those areas in accessing mental health services. ${ }^{2}$ Other serious obstacles are stigmatization for psychiatric disorders and patients' experiencing difficulties in continuing their appointment. ${ }^{3}$ The Internet has become widespread, and telepsychiatry practices are promising to overcome these obstacles. In the literature, "telepsychiatry" is defined as psychiatric evaluations and treatments conducted by using telecommunication technologies. In the present article, the term telepsychiatry will be used for evaluations and interventions made by videoconferencing. The fact that psychiatric examination is interview-oriented and less dependent on physical examination has made telepsychiatry more accepted in telehealth practices. Telepsychiatry, which was first tried in the 1950s and gained speed in the early 2000s, has been increasing in recent years. ${ }^{4}$ Contrary to both professionals' and clients' concerns, it has been reported that telepsychiatry interviews are not different from conventional interviews, and it has even been stated in some studies that patient satisfaction is higher. ${ }^{5}$ Telepsychiatry, which can be applied anywhere with internet access, has created a new working area for the clinician that has to work in a small room. Interviews with the educator

Address for Correspondence/Yazıșma Adresi: Sefa Coșğun, Van Training and Research Hospital, Clinic of Child and Adolescent Psychiatry, Van, Turkey

Phone: +90 5067594368 E-mail: drsefacoskun@gmail.com ORCID: orcid.org/0000-0003-2843-6554

Received/Geliș Tarihi: 23.11.2020 Accepted/Kabul Tarihi: 17.01.2021

${ }^{\circ}$ Copyright 2021 by the Turkish Association for child and Adolescent Psychiatry / Turkish Journal of Child and Adolescent Mental Health. published by Galenos Publishing House. 
and the family for diagnosis and treatment, remote forensic examinations in prisons, telepsychiatry interviews in primary healthcare institutions, and emergency outpatient clinics are some of these. ${ }^{6}$ Besides, doing interviews in environments where children and adolescents live can make them feel like they have control and feel more comfortable. It also provides the interviewer the chance to make observations in the children and adolescents living in. ${ }^{7}$

The Coronavirus disease-2019 (COVID-19) outbreak, which appeared in December 2019 in Wuhan, China, affected the whole world and had severe consequences on human health. It is recommended to comply with personal protection and social distance rules to slow down the outbreak's spread. Also, a curfew was imposed on children and adolescents in Turkey for a while. The stress levels that increased with the measures taken caused the treatment of children and adolescents to be interrupted and psychopathologies to appear in some children and adolescents who did not have the mental disease. ${ }^{8}$ Although the advantages of telepsychiatry practices were also known before the outbreak, it began to be used widely in the whole world because of the difficulty to access the increasing needs and health services during the pandemic. ${ }^{9}$ In Turkey, telepsychiatry has gained momentum with the pandemic, and patient satisfaction was considerably high in the first study in Turkish literature. ${ }^{10}$ In this article, cases followed by teleconference via doxy.me (www.doxy.me) during the COVID-19 outbreak will be presented. For the interviews, doxy.me, which is frequently used for telemedicine interviews in the world, was used due to the lack of an interview platform prepared for telemedicine in our country. The advantages of doxy.me over other platforms that offer services in this field are as follows: it has security certificates, and that this service is offered free of charge to the interviewers, it is very easy to use (the clients can participate in the interview by just typing their names before starting the interview), the parties do not have to install any program. The standardized procedure was not followed in the interviews, and interviews were done regarding the needs of the family, children and youth. Although there was no time limitation, some interviews (follow-up and medication regulation) were shorter than face-to-face interviews. In each case, the first interviews were made with the family, in some cases (case 2 and case 4); the youth was interviewed alone. The interviews were held at suitable times for the parties during the day, and the clinician provided all resources (i.e., computer, internet connection, camera, microphone, room lighting) with their own means.

Before starting the interviews, the subjects were informed about telepsychiatry's limitations and disadvantages (such as technology-related problems, lack of legal regulations, emergencies). ${ }^{11}$ The authors obtained informed consent forms for telepsychiatry interviews from the patients and their families.

\section{CASE 1: Attention Deficit and Hyperactivity Disorder}

The 9-year-old male patient has been followed up with a diagnosis of Attention Deficit and Hyperactivity Disorder (ADHD) for two years. After formal education was interrupted during the COVID-19 outbreak to decrease the spread of the virus, the parents called to ask through teleconferencing whether they would continue the ADHD drugs their child was using. The family said that the attention problems were not evident, and that the child could study by giving frequent breaks. They stated that their child's hyperactivity complaints increased because he had to spend more time at home and had difficulty in spending time with their child at home. The mother said that the case quarreled with his brother, and the problems continued despite their interventions. During the interview, it was observed that the case could not continue the interview for a sufficient amount of time. His attention was frequently distracted. He was about to fall off the sofa a few times due to hyperactivity. Upon this, it was discussed with the family how they could intervene in the behavioral problems and the physical activities that could be done at home. It was decided to continue medical treatment for ADHD.

\section{CASE 2: Major Depressive Disorder}

A 17-year-old female patient was referred to our clinic with complaints of lack of energy, loss of motivation, and disruptions in sleep pattern before the COVID-19 outbreak; she was diagnosed with Major Depressive Disorder and followed up with cognitive-behavioral therapy (CBT) and sertraline $50 \mathrm{mg} /$ day. The case and her family experienced problems in continuing their clinical follow-up due to the measures taken within the pandemic (such as curfew for children and adolescents and a decrease in transportation options). It was decided to continue the weekly on-going therapy sessions with the family and the case via telepsychiatry at the same frequency. Before starting telepsychiatry sessions, emergencies were evaluated. The steps to be followed were decided with the patient and the family. In the face-to-face meeting, a session was held that included psychoeducation of major depressive disorder (MDD), the basics of CBT, and the emotion-thought-behavior triangle. In the following telepsychiatry sessions, especially automatic thoughts, were worked on. Cognitive studies were worked on due to measures taken during the pandemic. It was found that depressive symptoms of the case decreased significantly, and a significant recovery was observed in functionality after the fifth telepsychiatry meeting. Thus, the telepsychiatry sessions were organized monthly. The case is currently being followed by sertraline $50 \mathrm{mg} / \mathrm{day}$, and she continues to be in remission.

\section{CASE 3: Autism Spectrum Disorder}

After their 6-year-old daughter's behaviors changed during the COVID-19 pandemic, the family living outside Turkey wanted a teleconference meeting since they could not access child and adolescent mental health services in the area, they were living in. The family said that their daughter started making strange hand gestures for the last two weeks, and she went back and forth in the house. They stated that she had these movements more when she was younger, but they had not observed them recently. They said that after the pandemic started, their daughter's appetite gradually decreased, she washed her 
hands more often, and she was extremely irritated. When her developmental history was evaluated, it was learned that she started meaningful words at the age of two and constructed sentences at the age of three. Although language developed in time, her social interaction and communication skills lagged behind and she preferred to spend time alone in most of the social environments. In other developmental areas, there was no noticeable deviation from her peers. Since the meeting was held on the family's mobile device, the whole family had difficulty being in the same frame. During the meeting, the case was continually on the move and did not establish a mutual relationship for a long time. When she tried to communicate, she clapped her hands in excitement and disappeared from the screen, and the family explained this with their daughter's being shy. The family also added that their daughter did not have too many friends. Although the case did not fully meet the diagnostic criteria of sensory hypo-hypersensitivity and limited area of interest for Autism Spectrum Disorder (ASD), she was thought to have ASD. Behavioral recommendations were made to the family. They were recommended to apply to the pediatric mental health center near to their home for more detailed evaluation and effective educational interventions.

\section{CASE 4: Substance Use Disorder}

A 17-year-old male applied to our clinic about a year ago due to methamphetamine use. On admission, he had been smoking a pack of cigarettes a day, and had been using methamphetamine four days a week for two years. The case who did not have alcohol consumption and had applied for treatment voluntarily. He was hospitalized at the Child and Adolescent Substance Addiction Treatment Centre for treatment. The patient, who received risperidone $1 \mathrm{mg}$ /day treatment on hospitalization, was also taken in a 12-step addiction treatment program. After the addiction treatment was completed, the case was discharged. He and his family were informed about the issues to pay attention to abstain substance use. During the follow-up, it was learned from the case and the family that he did not use the substance again, and no evidence of substance use was found in the tests conducted. However, it took about 4 hours for the case and his family to get to the treatment center, which made clinical follow-up difficult. With the COVID-19 outbreak, this difficulty increased even more. Upon this, it was decided to continue the sessions through teleconference by collaborating with the family and the patients. While the motivational sessions continued via teleconference, the child psychiatry clinic in the city they lived in was contacted, and it was ensured that psychopharmacological treatment continued there. The patient, who is followed with motivational telepsychiatry sessions at regular intervals, continues his life without substance use. It was found that the satisfaction and treatment compliance of the case and his family increased after telepsychiatry sessions.

\section{Discussion}

With COVID-19 outbreak, telepsychiatry applications have become more widespread in the whole world. ${ }^{9}$ Although telepsychiatry practices have been published in Turkish literature, there are no guidelines prepared for children, adolescents and families. ${ }^{12-13}$

In this article, cases followed with telepsychiatry service, which may be a solution to the difficulties mentioned above to a great extent, were presented. ${ }^{14}$ The cases were selected among the cases frequently encountered in child and adolescent psychiatry clinical practice, such as Neurodevelopmental Disorders and Mood Disorders. In addition, due to the limited number of special clinics for Alcohol and Substance Addiction treatment in Turkey, another patient who applied for those problems was chosen to increase their access to treatment. Patients and families who had the neccesary equipment, access to the internet and were willing to be interviewed by teleconference methods were selected for presentation.

The most recent epidemiological study conducted in our country found that approximately one out of ten children had ADHD. ${ }^{1}$ Many studies have shown how negative the course can be when such a frequent disorder is not diagnosed and when suitable interventions are not made. ${ }^{15}$ The measures taken within the scope of COVID-19 outbreak can be quite challenging for children with ADHD complaints. In the first case in the present article, a case with increased hyperactivity complaints due to staying at home was presented. It is a known fact that ADHD is not only an academic difficulty, but it is also accompanied by social, emotional, and behavioral difficulties. ${ }^{15}$ It is known that during the COVID-19 outbreak, cases with ADHD may have more difficulty in participating in online lessons, being organized, controlling time, regulating affect and adjusting social distance with people when compared with their typically developing peers. For these reasons, it is recommended that cases receive treatment for ADHD to continue their treatment without giving a break. ${ }^{16}$ It is thought that family education, which has been shown to be effective in ADHD treatment in many studies, may also be effective in this period. ${ }^{17}$

There were problems in the follow-up and treatment of many cases receiving mental health care services before the pandemic. The second case presented in the article is a case that was followed up in person with a diagnosis of MDD but who continued with telepsychiatry sessions with the start of the pandemic so that her therapy would not be affected. During the pandemic, there was an increase in the anxiety and depression symptoms of individuals. The risk of relapse and recurrence was found to increase in individuals with anxiety and mood disorders. ${ }^{8}$ This risk increases even more with the problems during the treatment process. Considering the nature of MDD (lack of energy, anhedonia, sleep problems, stigma, etc.), the satisfaction rates of patients with MDD from telepsychiatry are very high. ${ }^{6}$

Immigrant children and their families' language and communication problems are among the obstacles to receiving ideal mental health services. These problems may cause delayed diagnosis of disorders such as ASD, in which early diagnosis is important. ${ }^{18}$ It was found that behavioral problems increased 
in cases with ASD as a result of the measures taken with the pandemic. ${ }^{19}$ Cases with ASD, who have limited social interaction skills and outlets, got lonelier during the pandemic, and their problems increased. Also, poor immune response, not being able to adjust the social distance, and low self-care skills that can be seen in ASD make the children in this group riskier in terms of COVID-19. ${ }^{20}$ The article also presents a possible ASD case whose family was living in a country in the Eastern European region and who applied for evaluation due to the increasing obsession of their child during the pandemic. The family, who could not get help because no professionals were working in pediatric mental health in their region, could not find an effective intervention opportunity for chronic relational problems in their child. Telepsychiatry practices have a crucial role for ASD cases and their families, including immigrants with language barriers, advising families on behavioral problems, regulating the medicines with short interviews, and most notably, in early diagnosis.

Finally, a case referred to the clinic with methamphetamine use about a year ago and who was followed with telepsychiatry during the pandemic was presented. Substance use disorder (SUD) treatment has some limitations, such as weak compliance of the patient and their families to treatment, stigmatization against substance addicts, and a limited number of treatment centres. ${ }^{21}$ In addition to these, with the COVID-19 pandemic, stress levels of patients with SUD have increased. Their access to treatment has become more difficult, and their social support has weakened. It is known that these patients' immune systems are weak in general, and methamphetamine use is associated with pulmonary and cardiac diseases. ${ }^{20}$ When the treatment needs and risky situations of SUD diagnosed patients during the pandemic are considered, it can be seen that telepsychiatry practices provide solutions for the difficulties in the treatment processes of these cases.

Although telepsychiatry practices provide opportunities for patients and practitioners in many fields, their long-term results are still unknown. This practice, which can be considered novel, has some on-going problems such as evaluating nonverbal communication, interviewing cases with hearing and sight problems, establishing therapeutic relationships, performing a physical examination. ${ }^{9}$ Besides, ethical problems such as the confidentiality of the patient-physician relationship in telepsychiatry practices, what to do in case of an emergency, what to do in case of problems with the equipment and services used during the interview, and the training of the practitioners still await solutions. ${ }^{11}$

\section{Conclusion}

During the pandemic period, when mental health services are needed more than ever, it has been very difficult for children and adolescents to access these services with the measures taken. Mental health services should be more easily accessible, and new methods should be tried for early diagnosis and interventions. In addition to decreasing the risk of being infected with COVID-19 for healthcare professionals and patients, telepsychiatry also provides a large number of new opportunities in the field of mental health. Since the difficulties experienced during the COVID-19 period will neither be the first nor the last, legal regulations should be made to increase the routine use of telepsychiatry in our country, and guidelines should be provided for those working in the field.

\section{Ethics}

Peer-review: Externally and internally peer-reviewed.

\section{Authorship Contributions}

Concept: S.Ç., E.F., Design: S.Ç., E.F., Analysis or Interpretation: S.Ç., E.F., Literature Search: S.Ç., E.F., Writing: S.Ç.

Conflict of Interest: No conflict of interest was declared by the authors.

Financial Disclosure: The authors declared that this study received no financial support.

\section{References}

1. Ercan ES, Polanczyk G, Akyol Ardıc U, Yuce D, Karacetın G, Tufan AE, Tural U, Aksu H, Aktepe E, Rodopman Arman A, Başgül S, Bılac O, Coşkun M, Celık GG, Karakoc Demırkaya S, Dursun BO, Durukan I, Fidan T, Perdahlı Fiş N, Gençoğlan S, Gökçen C, Görker I, Görmez V, Gündoğdu ÖY, Gürkan CK, Hergüner S, Tural Hesapçığlu S, Kandemir H, Kılıç BG, Kılınçaslan A, Mutluer T, Nasiroğlu S, Özel Özcan Ö, Öztürk M, Öztop D, Yalın Sapmaz S, Süren S, Şahin N, Yolga Tahıroglu A, Toros F, Ünal F, Vural P, Perçinel Yazıcı İ, Yazıcı KU, Yıldırım V, Yulaf Y, Yüce M, Yüksel T, Akdemir D, Altun H, Ayık B, Bilgic A, Hekim Bozkurt Ö, Demirbaş Çakır E, Çeri V, Üçok Demir N, Dinç G, Irmak MY, Karaman D, Kınık MF, Mazlum B, Memik NÇ, Foto Özdemir D, Sınır H, Ince Taşdelen B, Taşkın B, Uğur Ç, Uran P, Uysal T, Üneri Ö, Yilmaz S, Seval Yılmaz S, Açıkel B, Aktaş H, Alaca R, Alıç BG, Almaidan M, Arı FP, Aslan C, Atabay E, Ay MG, Aydemir H, Ayrancı G, Babadagı Z, Bayar H, Çon Bayhan P, Bayram Ö, Dikmeer Bektaş N, Berberoğlu KK, Bostan R, Arıcı Canlı M, Cansız MA, Ceylan C, Coşkun N, Coşkun S, Çakan Y, Demir İ, Demir N, Yıldırım Demirdöğen E, Doğan B, Dönmez YE, Dönder F, Efe A, Eray Ş, Erbilgin S, Erden S, Ersoy EG, Eseroğlu T, Kına Fırat S, Eynallı Gök E, Güler G, Güles Z, Güneş S, Güneş A, Günay G, Gürbüz Özgür B, Güven G, Çelik Göksoy Ş, Horozcu H, Irmak A, Işık Ü, Kahraman Ö, Kalaycı BM, Karaaslan U, Karadağ M, Kılıc HT, Kılıçaslan F, Kınay D, Kocael Ö, Bulanık Koç E, Kadir Mutlu R, Lushi-Şan Z, Nalbant K, Okumus N, Özbek F, Akkuş Özdemir F, Özdemir H, Özkan S, Yıldırım Özyurt E, Polat B, Polat H, Sekmen E, Sertçelik M, Sevgen FH, Sevince O, Süleyman F, Shamkhalova Ü, Eren Şimşek N, Tanır Y, Tekden M, Temtek S, Topal M, Topal Z, Türk T, Uçar HN, Uçar F, Uygun D, Uzun N, Vatansever Z, Yazgilı NG, Miniksar Yildız D, Ylldız N. The prevalence of childhood psychopathology in Turkey: a cross-sectional multicenter nationwide study (EPICPAT-T). Nord J Psychiatry. 2019;73:132-140.

2. Michalski DS, Kohout JL. The State of the Psychology Health Service Provider Workforce. Am Psychol. 2011;66:825-834.

3. Savin D, Glueck DA, Chardavoyne J, Yager J, Novins DK. Bridging cultures: Child psychiatry via videoconferencing. Child Adolesc Psychiatr Clin N Am. 2011;20:125-134.

4. Wittson CL, Benschoter R. Two-way television: helping the Medical Center reach out. Am J Psychiatry. 1972;129:624-627.

5. Crum KI, Comer JS. Using synchronous videoconferencing to deliver family-based mental healthcare. J Child Adolesc Psychopharmacol. 2016;26:229-234.

6. Myers K, Cain S; Work Group on Quality Issues; American Academy of Child and Adolescent Psychiatry Staff. Practice parameter for 
telepsychiatry with children and adolescents. J Am Acad Child Adolesc Psychiatry. 2008;47:1468-1483.

7. LL Carlisle. Child and Adolescent Telemental Health. In: Mayers K, Turvey CL, eds. Telemental Health: Clinical, Technical, and Administrative Foundations for Evidence-Based Practice. Waltham MA; Elsevier; 2013:197-221.

8. Rajkumar RP. COVID-19 and mental health: A review of the existing literature. Asian J Psychiatr. 2020;52:102066.

9. Chen JA, Chung WJ, Young SK, Tuttle MC, Collins MB, Darghouth SL, Longley R, Levy R, Razafsha M, Kerner JC, Wozniak J, Huffman JC. COVID-19 and telepsychiatry: Early outpatient experiences and implications for the future. Gen Hosp Psychiatry. 2020;66:89-95.

10. Dursun OB, Turan B, Gulsen M, Karayagmurlu A, Tugce Mustan A, Kutlu A, Rodopman Arman A, Gokcen C, Dogru H, Esin IS, Kaya I, Coskun M, Soylu N, Erbilgin S, Tanir Y. Caring for the most vulnerable: a model for managing maladaptive behavior in children with mental special needs during the COVID-19 pandemic. Telemed J E Health. 2020.

11. Usta MB, Sahin I. Telepsychiatry Practices and Ethical Challenges in the COVID-19 Pandemic. In: Ercan ES, Yektas C, Tufan AE, Bilac O, eds. COVID-19 Pandemic and Child and Adolescent Mental Health, 1st ed. Ankara; Turkiye Klinikleri; 2020:136-140.

12. Karaş H. İyi Telepsikiyatri Uygulaması için Öneriler. Türkiye Psikiyatri Derneği. Erişim: https://www.psikiyatri.org.tr/2151/iyitelepsikiyatri-uygulamasi-icin-oneriler

13. Yorulmaz O, Derin S, Yorulmaz EG, Gültekin G, Baş S. Çevrimiçi Psikolojik Müdahale ve Uygulamalar için Telepsikoloji Kılavuzu. 2020. Erişim: https://www.psikolog.org.tr/tr/files/folder/ telepsikoloji-kilavuzu-x150.pdf

14. Scott Kruse C, Karem P, Shifflett K, Vegi L, Ravi K, Brooks M. Evaluating barriers to adopting telemedicine worldwide: A systematic review. J Telemed Telecare. 2018;24:4-12.
15. Biederman J, Faraone SV. The effects of attention-deficit/ hyperactivity disorder on employment and household income. MedGenMed. 2006;8:12.

16. Cortese S, Asherson P, Sonuga-Barke E, Banaschewski T, Brandeis D, Buitelaar J, Coghill D, Daley D, Danckaerts M, Dittmann RW, Doepfner M, Ferrin M, Hollis C, Holtmann M, Konofal E, Lecendreux M, Santosh P, Rothenberger A, Soutullo C, Steinhausen HC, Taylor E, Van der Oord S, Wong I, Zuddas A, Simonoff E; European ADHD Guidelines Group. ADHD management during the COVID-19 pandemic: guidance from the European ADHD Guidelines Group. Lancet Child Adolesc Heal. 2020;4:412-414.

17. Katzmann J, Hautmann C, Greimel L, Imort S, Pinior J, Scholz K, Döpfner M. Behavioral and nondirective guided self-help for parents of children with externalizing behavior: mediating mechanisms in a head-to-head comparison. J Abnorm Child Psychol. 2017;45:719730.

18. Mandell DS, Listerud J, Levy SE, Pinto-Martin JA. Race differences in the age at diagnosis among medicaid-eligible children with autism. J Am Acad Child Adolesc Psychiatry. 2002;41:1447-1453.

19. Colizzi M, Sironi E, Antonini F, Ciceri ML, Bovo C, Zoccante L. Psychosocial and behavioral impact of COVID-19 in autism spectrum disorder: An online parent survey. Brain Sci. 2020;10:341.

20. Pardo CA, Vargas DL, Zimmerman AW. Immunity, neuroglia and neuroinflammation in autism. Int Rev Psychiatry. 2005;17:485-495.

21. Farhoudian A, Baldacchino A, Clark N, Gerra G, Ekhtiari H, Dom G, Mokri A, Sadeghi M, Nematollahi P, Demasi M, Schütz C, Hashemian S, Tabarsi P, Galea-Singer S, Carrà G, Clausen T, Kouimtsidis C, Tolomeo S, Radfar SR, Razaghi E. COVID-19 and Substance Use Disorders as Brain Diseases: Recommendations to a Comprehensive Healthcare Response. An International Society of Addiction Medicine (ISAM) Practice and Policy Interest Group Position Paper. Basic Clin Neurosci J. 2020;11:133-150. 